\author{
Kateryna Shaulis Катерина Шауліс \\ Senior Lecturer, Department of Ukrainian Studies, Kharkiv старший викладач кафедри українознавства Харківської \\ State Academy of Design and Art Аержавної академії дизайну і мистецтв \\ тел. / tel: +380660980265 e-mail: kzhernoklova@gmail.com orcid.org/0000-0003-4029-5790
}

\title{
Reminiscence of Theatrical Engraving in the Japanese Eco-posters
}

\author{
Ремінісценції театральної гравюри \\ в японському екологічному пцакаті
}

\begin{abstract}
The high rise of the Japanese theatrical engraving as a self-sufficient and independent art is observed in the $17^{\text {th }}-19^{\text {th }}$ centuries and has no analogies not only in the culture of other Eastern countries, but in the whole world culture in general. Extremely strong influence on the modern ecological poster had the work of Tusyushai Syaraku. The peculiarity of the artistic manner of Syaraku is that in his work he embraced almost the full spectrum of the theater performing staff, and not just the popular "stars". The circle of characters in Syaraku is more complete and "democratic", in comparison with other masters. Among the modern masters who were influenced by the work of Tosyushaya Syaraku, we note Takanokuro Yoshinori, Norizako Kita, Shuzo, Sato Koichi and many others. In their posters, masters use o-kubi-e techniques.

Keywords: Japanese theater engraving, ecological poster, Tusyushai Syaraku prints, o-kubi-e.
\end{abstract}

Problem statement. The problem of efficient environmental management and respect for the environment is becoming more and more pressing and acute with each passing year. The main cause of global environmental problems is irrational environmental management. The level of pollution of the planet increases every year.

The international triennial $4^{\text {th }}$ Block was created as a response to environmental problems that arose after the 1986 explosion at the Chernobyl nuclear power plant. However, the role and goals of the triennial are not limited to this. Over the years of its existence, the festival has expanded and grown into a global environmental project, with its participants interested not only in the problems of nuclear pollution, but in the general ecological picture of the world.

The novelty of the exhibition project, the gradual accumulation of its experience and the accumulation of visual information determined a certain narratives of a significant part of publications, the main content of which is statistical data on participants and winners of the competitive part of the $4^{\text {th }}$ Block festival, among which a significant place is occupied by masters from Japan. Therefore, the art history research of an eco-poster develops gradually, and the need to process the accumulated material seems very relevant in our time.

Objectives: to trace the influence of the Japanese theater engraving on the formation of the artistic language of Japanese ecological poster.
Analysis of recent research works and publications revealed that the noted aspect of Japanese prints is considered in the article by S. Rybalko "Japanese Costume". The researcher notes that the practice of publishing advertising series was quite common and significantly influenced the development of a stereotypical composition, which included the image of a woman in the back, the best way to demonstrate kimono patterns. To create advertising series, the owners of fabrics and ready-made shops tried to attract the most famous artists, for example, Isoda Korusay, Torii Kiyonaga, Kikugava Eizan, Utagava Kunimasi, Katsushika Hokusai, Kaysai Eisen, etc. For instance, beautiful models in the works of Utagawa Kunimasi and Katsushiki Hokusai, their compositional decisions were completely subordinated to the goal of demonstrating all components of the costume, fashionable fabrics and decorations [11].

In fact, remaining outside of scientific research, the problems of modern Japanese poster are the subject of active discussions by practical designers, in various kinds of blogs, on professional forums and websites. Indicative in this regard is the Internet discussion, which has developed on one of the sites [3]. The subject of discussion was a poster created by the American master James White. The theme of the poster-environmental tragedy (Japan 2011) — set the discussion in the appropriate direction. It should be noted that network sources of information are more operational in covering the problems of the modern globalized world, therefore, 
they, and not academic publications, first of all become a platform for discussing urgent professional tasks of designers. In connection with this trend, we believe that the inclusion of materials from the world wide web of Internet into a circle of sources along with traditional, museum, visual and literary ones is quite appropriate.

According to E.Serdyuk, theatrical engraving is on the verge of two arts-visual and scenic. That is why the characteristic features of time, specifically reflected in each of these arts [12], are most clearly manifested in theatrical engraving. Engravings and popular prints that dealt with the theatrical themes were fairly widespread both in the East and in Europe in the late Middle Ages. Nevertheless, in most cases, theatrical schedule was secondary, remaining only an auxiliary kind of art relative to the theater.

The rise of the art of Japanese theater engraving, its formation as a self-sufficient and independent phenomenon, which was observed since the $17^{\text {th }}$ through the $19^{\text {th }}$ centuries, has no analogues not only in the culture of other Eastern countries, but also in the entire world culture.

The life simplicity of folk tastes, which was reflected in Japanese prints, especially theatrical, does not detract from its significance as a complex and multifaceted art. In comparison with the court and monastic culture of the past, it has its merits and grace, despite the lack of elite sophistication. The main motives are the freshness of lyrical perception, open life-giving power, and festive sublime feelings.

These qualities, which made it the leading genre of Japanese art at the turn of the Middle Ages and New Times, are also of unrelenting interest in our time [12].

Presentation of the main research material. The work of Tusyushai Syaraku (ca. 1770-1825 (?)) had an extremely strong influence on the modern ecological poster. The master, whose creative period was extremely short ( 9 or 10 months), left a big mark in the history of Japanese engraving (144 works), influencing modern masters. His artistic legacy includes a large number of portraits of actors. According to some reports, Syaraku himself was an actor in the kabuki theater. However, reliable biographical data on Syaraku has not been found. His works have subtle and flexible lines: on a dark gray, almost uniform background, portraits of characters are shown as a bright spot. Basically it is one or two-figure compositions, made in full length or up to the chest. Creating portraits of his heroes, the artist applies the principle of generalization. Using only a few lines, the author manages to convey a deep psychological portrait of the depicted characters. Usually, Syaraku's compositions are Okubi-e, with grotesque portraits of actors on a dark, sometimes flickering background, which is shaded with the help of the Kira-e technique. Expressions of grimaces on faces, often exaggerated to caricature, in conjunction with the drama, which is provided for by the meager gestures, convey not only the character of the plays, but also the personality traits of the actor. In a strong drawing of Syaraku and skillful use of color contrasts, all the technical possibilities that were available to the artist of his time were used. According to Gabriel Far-Becker, the assumption that highly realistic, not always flattering portraits caused hostility of the public and hate of the actors towards the artist is nothing more than a legend, although this explains his sudden disappearance [12, p. 196].

The absolute truth is that the Japanese public was not ready for Syaraku's sarcastic realism of art or for his caricatures based on psychological knowledge. Both of these phenomena have become revolutionary in the art of ukuyu-e and can be considered the causes of an extremely short period of creativity for Syaraku.

The peculiarity of the artistic manner of Syaraku is that in his work he embraced almost the full range of the performing staff of the theater, and not just the popular "stars". The circle of characters in Syaraku, in comparison with other masters, is more complete and "democratic". Choosing a topic for work, he did not limit himself with the ranks, popularity, reputation, or name of an actor; he was pointedly informal and did not depend on the conjuncture of actor's fame. Syaraku was interested in the dramatic basis of the play, the life of the characters on the stage, so he quite boldly interprets the characteristic features of their appearance. Naturally, this approach was most closely related to the type of bust portrait Yakusya-Nigao-e. With them begins a chronological list of Syaraku works. The best are his first works - busty images of actors on large-sized paper oban, on a smooth uniform background, which were performed in May-July 1794.

For backgrounds, Syaraku often used dark, greenish-gray tones with mica powder, which created a representation of the metallic luster of the surface. On such a deafening background, the white color of the paper, the charcoal-black color of the characters' hair, the whole range of colors that were used during the image of fabrics and costume jewelry look especially elegant.

Syaraku relied on the advanced technique of polychrome woodblock print, because the solutions for his engravings are quite diverse. However, it is possible to single out the general features of his palette: complex, muted colors, noble simplicity and restraint in the use of ornamental motifs. The fact that Syaraku has enveloped his passionate, sometimes furious insults in the most delicate dark colors, gives his works a unique charm.

Among the group of works that were performed by Syaraku in May-July 1794, is the woodblock print, created for the play Koi's Ego of the Somavak Tatsuna (in the Russian translation by V. Brand-Night song of the Driver Yosakuiz Tamba), are of particular interest. It is not a simple set, but a consistent series with exposure, climax and decoupling, embodied in the portraits of different characters. The robber and noble man Takemura Sadanosina is depicted with a special emotional accent.

In the engraving of Syaraku, actor Otani Oniji II, who plays the role of Yakko Adobey, stuns the viewer with the power of his emotional outburst. The engraving, which was created by sufficiently clear "strokes" of the brush of a talented graphic hand, conquers with the special precision of the drawing, the only pose and gestures of the hero, which helps to reveal and see the image of the evil, active, attacker. The lack of anatomical correctness in the image of the hands does not diminish the skill of execution, but, 
on the contrary, helps to emphasize the greedy and angry character of the hero. The costume moves and "plays" along with the character, emphasizing the predatory plasticity of his movements, and at the same time points to refined grace.

In the engravings of the second half of 1794 and of 1795 , Syaraku switched to the format of khosoban and full-length single-figure compositions. This characteristics, almost grotesque work, accurately and sharply conveys the emotions and poses of the characters. Such author's attention to postures is predetermined, most likely, by a "posture culture" that is quite developed in Kabuki.

The author always clearly and even mercilessly reveals all the features of the characters, for which he quite often succumbed to criticism. Indeed, in his works, Syaraku did not seek to decorate the actors. The master portrayed his characters with all the "palette" of stupid manners that were inherent in the portrait. Therefore, Umataro, outraged by such works of Syaraku, wrote that "bad habits" can be traced in the portraits of actors, and this condemnation of the schedule is perceived as a certain kind of praise.

Despite the fact that Syaraku based himself on the achievements of his predecessors, there is an unusual, sometimes hostile manner in relation to traditions in his works. In the art of Syaraku, a violation of the once integral system of conventions is noticeable: the creator's view with ingenious insight penetrates through the numerous "shells" of the image much deeper than was envisaged by the canon. The flash of feelings that Syaraku catches, mercilessly illuminates the deep, hidden qualities of human nature.

Despite all the laconism, in the works of Syaraku there are clearly separated "layers" of the image. The upper onescanonical makeup, hairstyle, costume - constitute the classic viewer's thought. Next comes the mimic scheme that characterizes a particular character, at a particular point in the development of the action. Under such a mimic mask, portrait features of the performer's appearance are often traced: proportions, facial contours, patterns, eyes, nose, lips, and through them, the age-specific features of the character can be traced.

So, according to E. Serdyuk, in the works of Syaraku, various emotional states and the most vivid characters were conveyed with great sharpness and brilliance. In each of Syaraku's engravings, only one, albeit the most important at the moment, aspect of the character's spiritual world is displayed. This is a strong, but instantaneous surge of feelings, and not the final logical development of character in all the complexity of its relationship with the outside world. Such images of their emotional power are designed to focus the viewer's attention on the main thing, neglecting the secondary. It is not difficult to notice that this very principle of selection and concrete methods of exaggerating the important and negligent insignificant were the basics of theatrical vision and formed the basis of all Japanese theatrical aesthetics [12].

Thus, it is impossible not to agree with the majority of researchers that the images of Syaraku are multidimensional, but this feature of them has nothing to do with both subjective self-will and psychology, with a multilateral coverage of the personality of the characters. Their complexity is not the end of a complex psychological construction, but is the result of the destruction of the late medieval canonical foundations. This also implies the peculiarity of Syaraku's works, which consists in the fact that the concept of an actor and the role in his engravings is not only different, as in most other graphs, but can also be contrasted.

Among the masters of engraving, ukiye-e Tosyushai Syaraku was the closest to the poster solution of his engravings. Moreover, perhaps, for this reason, he is one of the most cited masters of the present time. Inspired by the creativity of Syaraku, the masters of contemporary ecological poster create a number of works in which the influences of this talented master are quite clearly traced. In Ando Hiroshige's work Syaraku, we see a clear imitation of the style and techniques of the master. Starting with the name of the work, which directly indicates the name of the famous predecessor. The yellow background plays the role of some kind of curtain, through which, when opened a little, the actor looks at us. The conciseness of the techniques that are used clearly indicate an imitation of the creativity of Syaraku.

In the work of Naoya Muratu, the relationship with Ando Hiroshige's Syaraku work is traced. The author does not take the Hiroshige engraving as a basis, he imitates only laconic and "scented" technique. On a yellow-green background there is an image of a tree, the trunk of which is slightly widened in its lower part, and from it, as if from behind a curtain, slightly supported by hand, eyes are looking at us. A similar trick was used by Ando Hiroshige in his work Syaraku.

Masakazu Tanabe developed two posters, which also titled Syaraku. However, the creative heritage of the famous graphics, he uses as a background. On the first poster we see the engraving "Actor Ichikawa Komazzo III in the role of Shigano Daisity", indicated by the silhouette of the hero, and Mon (family crest) on the actor's right shoulder. On top of the engraving, the author has placed a large rectangle that almost completely covers the face of the hero. Almost completely, the rectangle is painted white and only a thin red stripe, under which a small stretch from dark blue to blue is placed. As an accent in this rectangle is an image of the eyes, shaped like half the target. Obviously, Masakazu Tanabe thus sought to point out that our generation is destroying the past, destroying all the centuries-old legacy of constant conflicts, wars, polluting the atmosphere, because this rectangle seems to be superimposed on the face, closing most of it.

Thanks to the use of unpainted parts of the composition, an interesting optical effect is created: this white spot seems to spread over the entire plane of the sheet, turning it into a continuous white spot. According to the content, the mentioned poster is a warning: if people do not cease to destroy and pollute our land, after a certain time everything will disappear, turn into a dead white desert.

The second engraving by Masakazu Tanabe was designed using the same technique and depicts the actor Ichikawa Komadzo III in the role of Shiga no Dicity. That is, the basis for the poster was used the same engraving Tosyushai Syaraku. However, this time the face of the actor overlaps another rectangle, which with its unequal edges reminds us of a newspa- 
per or magazine clipping. The color used in the image is quite symbolic. Yellow and black are present in the color of the radiation hazard symbol, green is life, red is destruction and blood, black and white indicate dualistic concepts of life and death.

Enokido is another master inspired by the works of Syaraku. In their posters, which are called Syaraku, Enokido eclectically combines his vision and traditional techniques of graphics. Enokido takes only Syaraku's love for conciseness in depicting the silhouettes and faces of his characters as a basis for his work. Direct borrowing of images to Syaraku is traced in the center of the poster, where the contour-drawn faces resemble the make-up theater actors apply. Above and below the depicted characters there are two cartouches in which there are monks with the image of dragons and hieroglyphs, stylized ornaments and various elements.

O-Kubi-e ("big heads") in the system of genre subdivisions of Japanese theater engravings received the second name Yakusya-Nigao-e (portraits of actors). At the basis of this term is the concept of "similarities", which is obviously not accidental: at the end of the $18^{\text {th }}$ century, the problem of similarity became one of the central ones.

The introduction of bogus images made a real revolution in the art of woodcutting, bringing it to a significantly new, higher stage of development. The creation of bust portraits and in general the "fragmentation" of figures can be traced for almost the entire $18^{\text {th }}$ century. The main factor behind this rethinking of images in engraving was the evolution of ideas about man, as well as the growing need to create "recognizable" images of famous and beloved actors [14].

Examples of framing the figure, focusing on the character's face can be seen already in the belt images of Syunko. At the end of the $18^{\text {th }}$ century, the master creates a portrait of Sakata Sozyuro III, where all attention is concentrated on the face of an actor who plays the role of a thief.

The face in theatrical engraving is characterized, first of all, by make-up and mimicry [12]. With the advent of busting portraits, their character and the relationship between them changed. The classic make-up of Kumadori complied with color and linear symbolism, which is associated with the long tradition of physiognomy. Each role was answered by its placement and its own color. Mostly Kumadori decorated the face of significant, powerful characters, who were often shrouded in a halo of the supernatural. The make-up of other heroes was built according to the same laws as the central heroic Kumadori characters, but was less intense and vivid, only slightly emphasing the volume of the face [14].

The use of o-kubi-e techniques is reflected in the works of Japanese masters of ecological posters such as Norizaku Kita, Takanokura Yoshinori, Shuzo and Sato Koichi.

In his engravings of Norizaku Kita, RAVITY and LIVE imitates the main principle of o-kubi-e works. The posters present photographs of real children, and they are also the main "means of artistic expression", because only through children's faces the author conveys the idea of non-violence and life to the viewer.

Another striking example is the work of Takanokura Yoshinor Colors of the Future and The End of Nuclear
Inactivity. In the first case, we see a shoulder image of a person on a brown-red background. The contours of the chair and shoulders are modeled only with the play of light and shade, because the color of the body exactly matches the complexion. In the beginning, it seems that the character has its back to us, because it is impossible to distinguish any portrait features. However, having looked narrowly, we see that the image in a profile. This is indicated by the image of eyes that seem to look out to us from a tin can. With this technique, the author tries to tell everyone that if a person does not begin to take drastic measures, over time, everything and everything will turn into a faceless desert.

The work The End of Nuclear Inactivity is quite straightforward. On a white background, the image of two skulls is mirrored, the bulk and features of which are modeled by compressing and stretching the graphic grid. The absolute simplicity of the image and the use of white and black make the poster concise, but at the same time they put quite powerful content. The work represents the eternal struggle between good and evil, a good world and a negative nuclear threat.

In his posters, titled Life, Sato Koi only refers to the artistic techniques inherent in o-kubi-e. He, like most of the graphs of o-kubi-e, uses the principle of center composition. Choosing a white background as a basis for a poster, the author placed an image on it in the first case-a hat, in the second-the soles of the boots. In the work with a hat a tone stretch of the same color as the hat is placed around the main image. The contours of this stretch mark resemble the "mushroom" from the atomic bomb explosion. By this technique, the author points to the direct participation of man in the destruction of ecology and the World.

On the second poster from this series, there is also a tone stretch around the depicted soles, but behind the form it repeats the outlines of the soles. The radiation theme of this work is indicated by a rather interesting author's technique. The contours of human feet shine through the image of the soles, the image looks like an X-ray, the same rays that are released during a nuclear explosion. Thus, the author in this work also indicates the direct involvement of a person in the destruction of his world.

In the graph, ukio-e, which has been developing rapidly since the $17^{\text {th }}$ century, there are not only everyday scenes made in the technique of woodcuts, but also real advertising posters. A long period of time theatrical engraving occupied a leading place in the art of Japan. Such famous creators as Kiyonobu, Shunsko, Syaraku devoted their entire creative life to it. At the initial stage, absolutely all masters passed through the school of theatrical engraving, which was necessarily included in the training program for young artists, and served as a test of their professional maturity. The artists' workshops that were associated with theatrical engraving were the most well-established dynastic associations, and, often, the creative methods and forms of amenities compiled there extended to the artistic practice of engraving masters of all genres [12].

Some patterns of the Bijin-ga genre may be classified as an advertising poster by content, purpose, or artistic decision. 
For example, the work of the famous master Suzuki Harunobu Kasamori Osen and the Fan Vendor, in which the graph depicted Osen, the famous beauty of the time, in the process of acquiring a fan. All paper fans that the seller offers her depict monks and portraits of actors or theatrical scenes. Osen holds a fan with the Segawa Kikunodzho emblem; on the other fans it is easy to discern the monks of the Ichikawa and Otani dynasties. The entire list of goods is crowned by a fan with a bogus image of an actor in the style of Shunsho, two more of them depict actors in full length; and it is particularly interesting that Harunobu recreated on fans the signature of Buntho and Syunsho-the two largest masters of theatrical engravings of the late 1760 s and early 1770 s. There is no doubt that hints of involvement in theatrical consolations and awareness of the art of theatrical engravings bring additional touches to the characterization of Osen, as girls are not only good, but also savvy, being aware of artistic events.

Thus, an engraving rich in details, depicting not only the beauty, but also the fan vendor, makes this engraving a "double" advertising poster, because, on the one hand, the famous beauty Osen is popularized, and, on the other

\section{References}

1. Alferova Z.I. Granitsy vidimogo. Stanovleniye vizual'nogo iskusstva: monografiya. Kharkov: KHGAK, 2008. 268 s.

2. Gladun A.D. Ekologicheskiye plakaty «4 Blok» // Vestnik Khar'kovskoy gosudarstvennoy akademii dizayna i iskusstv. Khar'kov: KHGADI, 2007. № 3. S. 115-119.

3. Help Japan poster. URL: http://boingboing.net/2011/03/13/ help-japan-poster.html.

4. Asahi Shimbun. History of International Newspapers: Asahi Shimbun in Japan. Part 1. URL: http://www.trivia-library.com/a/history-of-international-newspapers-asahi-shimbun-in-japan-part-1.htm. 5. Japanese Prints and Posters URL: http://www.barewalls.com/index/japanese.

6. Lotman Y.M. Ob iskusstve: Struktura khudozhestvennogo teksta. Sankt-Peterburg: Iskusstvo-SPB, 1998. 704 s.

7. Serov S. I. Proshchay ekibana. KAK. 2000. № 11-12. S. 16-29.

8. Severina O. Problemy ekologicheskogo plakata «4-y Blok» // Vestnik Khar'kovskoy gosudarstvennoy akademii dizayna i iskusstv. Kharkov: KHGADI, 2007. № 1. S. 102-107.

9. V mezhdunarodnoye triyennale ekologicheskogo plakata 4-y Blok. Katalog-al'bom. Khar'kov: Konstanta, 2003. 174 s.

10. Vipper B.R. Vvedeniye $\mathrm{v}$ istoricheskoye izucheniye iskusstva: monografiya. Sankt-Peterburg: IZOGIZ, 2000. $342 \mathrm{s.}$

11. Rybalko S.B. Yaponskiy traditsionnyy kostyum: problemy atributsii: Vestnik Khar'kovskoy gosudarstvennoy akademii dizayna i iskusstv. Kharkov: KHGADI, 2014. № 4/5. S. 97-100.

12. Serdyuk A.A. Yaponskaya teatral'naya gravyura 17-19 vekov. Moskva: Iskusstvo, 1990. 129 s.

13. Tosyusay Syaraku (Toshusai Sharaku) - Yaponskiy Grafik i Aktyor. URL: http://allday.ru/index.php?newsid=169696.

14. Far-Bekker G. Yaponskaya gravyura: monografiya. Moskva: Artrodnik, 2005. $200 \mathrm{~s}$. hand, the celebrity advertises fans, which she chooses for herself, thus encouraging people to buy the same fans as hers. This technique is quite similar to modern advertising, picturing pop stars, movies or sports. The only difference is that modern advertising is aimed at promoting a particular brand, and the "old" one contains a general advertisement for fans.

The posters, which traditionally belong to the genre Yakusya-e, should also be attributed to advertising posters. The poster was an integral element of theatrical life, occupied a significant place in the popularization of Kabuki theater actors.

Conclusions. Thus, we can assert that Japanese theatrical engraving had a great influence on the formation of the modern language of the ecological poster. A special contribution to the development of the artistic language of the eco-poster was the work of Tosyushaya Syaraku. In his works, the techniques used (linearity, flatness, sensitivity in building a composition, using local spots, building a composition in contrast and nuance), were later adopted by the artists to create environmental posters. Theatrical engraving was of particular importance for the creativity of Takanokuro Yoshinori, Norizako Kita, Shuzo, Sato Koichi and others.

\section{Мітература}

1. Алфьорова 3.І. Межі видимого. Становцення візуального мистецтва: Монографія. Харків: ХААК, 2008. 268 с.

2. Гладун О.А. Екологічні плакати «4 Блок» // Вісник Харківської Аержавної академії Аизайну і мистецтв. Харків, 2007. № 3. С. 115-119. 3. Help Japan poster. URL: http://boingboing.net/2011/03/13/ help-japan-poster.html (last accessed: 15.08.2018).

4. Asahi Shimbun. History of International Newspapers: Asahi Shimbun in Japan. Part 1. URL: http://www.trivia-library.com/a/ history-of-international-newspapers-asahi-shimbun-in-japan-part-1. htm (last accessed 25.08.2018).

5. Japanese Prints and Posters. URL: http://www.barewalls.com/ index/japanese (last accessed 25.08.2018).

6. Аотман Ю.М. Структура художественного текста // Аотман Ю.М. Об искусстве. Санкт-Петербург: Искусство-СПб, 1998.704 с.

7. Серов С. Прощай, икебана! // Как. 2000. № 11-12. С. 16-29.

8. Северина О.М. Проблемы экологического плаката «4-й блок»

// Вестник Харьковской государственной академии дизайна и искусств. Харьков, 2007. № 1. С. 102-107.

9. V міжнародне триєнале екологічного плакату «4-й Блок»: Каталог-альбом / Укл. О. Векленко, О. Мадієвська, О. Северіна. Харьков: Константа, 2003. 174 с.

10. Виппер Б.Р. Введение в историческое изучение искусства. Санкт-Петербург: ИЗОГИЗ, 2000. 342 с.

11. Рибалко С.Б. Японський традиційний костюм: проблеми атрибуції // Вісник Харківської державної академії дизайну і мистецтв. Харків, 2014. № 4/5. С. 97-100.

12. Сердюк Е. А. Японская театральная гравюра 17-19 веков / поА реА. Р. В. Тимофеева. Москва: Искусство, 1990. 129 с.

13. Тосюсай Сяраку (Toshusai Sharaku) - японский график и актёр. URL: http://allday.ru/index.php?newsid=169696 (Аата обращения: 15.08.2018).

14. Фар-Бекер Г. Японская гравюра: Монографія. Москва: Артродник, $2005.200 \mathrm{c}$. 
Шауліс К.К.

Ремінісценції театрамьної гравюри в японському екомогічному пиакаті

Анотація. Високий змет японської театральної гравюри як самодостатнього і самостійного мистецтва спостерігається в XVIIXIX століттях і не має аналогій не тільки в культурі інших схіАних країн, а в усій світовій культурі. НаАзвичайно сильний вплив на сучасний екологічний плакат мала творчість Тосюсая Сяраку. Особливість художньої манери Сяраку полягає в тому, що в сво-

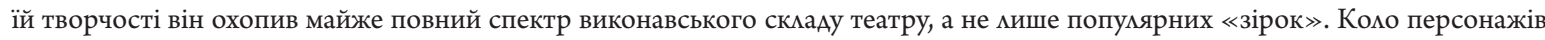
в Сяраку більш повне і «демократичне» порівняно з іншими майстрами. СереА сучасних майстрів, на яких вплинула творчість Тосюсая Сяраку, віАзначаємо Таканокуро Йошинорі, Норізако Кіта, Шузо, Сато Коичи і багато інших. У своїх плакатах майстри використовують прийоми о-кубі-е.

Ключові слова: японська театральна гравюра, екологічний плакат, гравюри Тосюсая Сяраку, о-кубі-е.

Шаулис К.К.

Реминисценции театрамьной гравюры в японском экомогическом пиакате

Аннотация. Высокий взмет японской театральной гравюры как самодостаточного и самостоятельного искусства, наблюдается в XVII-XIX веках и не имеет аналогий не только в культуре Аругих восточных стран, а и во всей мировой культуре в целом. Чрезвычайно сильное влияние на современный экологический плакат имело творчество Тосюсай Сяраку. Особенность хуАожественной манеры Сяраку заключается в том, что в своем творчестве он охватил почти полный спектр исполнительского состава театра, а не мишь попумярных «звезА». Круг персонажей Сяраку более полон и «демократичен», в сравнении с Аругими мастерами. Среди современных мастеров, на которых повлияло творчество Тосюсая Сяраку, отмечены Таканокуро Йошинори, Норизако Кита, Шузо, Сато Коичи и многие Аругие. В своих пиакатах мастера используют приемы о-куби-э.

Ключевые слова: японская театральная гравюра, экологический плакат, гравюры Тосюсая Сяраку, о-куби-э. 